\title{
NIETZSCHE Y LOS INTELECTUALES DE LA IZQUIERDA LATINOAMERICANA, 1900-1936
}

Fabio Moraga*

\section{Introducción}

Hace poco más de cien años, el 25 de agosto de 1900, falleció Friedrich Nietzsche, estaba loco, así había vivido sus últimos once años desde que terminara de escribir El Anticristo, maldición sobre el cristianismo. Desde ese momento en adelante el pensamiento de uno de los más polémicos filósofos alemanes, y que junto a Freud y Marx, fuera uno de los pilares fundamentales de la filosofía del siglo xx ha corrido toda suerte de peripecias. Sobre las consecuencias de su reflexión ha pesado una leyenda negra tejida implícita y soterradamente por la izquierda que lo ha culpado de ser uno de los pilares del nazismo. Sin embargo, a principios de siglo fueron los intelectuales y militantes de izquierda quienes leyeron en introdujeron el pensamiento de Nietzsche en varios países latinoamericanos. ¿Cómo articularon la evidente influencia de Nietzsche en su accionar político e intelectual?

A principios del siglo un sector de la intelectualidad latinoamericana, impelido por los profundos cambios de fin del siglo XIX y comienzos del XX, desarrolló un multifacético movimiento cultural antioligárquico

* Universidad de Chile. 


\section{FABIO MORAGA}

que se propagó por todo el continente. Este fenómeno fue protagonizado por grupos sociales juveniles y de clase media que se convirtieron en los nuevos actores de la historia de América Latina. Así, la acción de grupos o estamentos sociales que se sensibilizaron y tomaron conciencia del papel que les correspondía protagonizar en esta etapa, hizo que se vincularan a la política en medio de la crisis que dejaba fuera del escenario a los viejos partidos liberales y conservadores, surgiendo una serie de movimientos políticos que inauguraron el siglo XX. Estos grupos constituyeron una izquierda socialmente amplia, su composición abarcó desde obreros hasta algunos tránsfugas de la oligarquía, e intelectualmente fue heterodoxa y ecléctica en cuanto a las influencias, lecturas y formas como interpretaron y adaptaron los nuevos conocimientos.

Una noción muy generalizada plantea que los intelectuales latinoamericanos no 'producen' pensamiento original sino más bien lo ‘copian' de los centros de producción europeos y luego lo aplican a sus propias realidades sociales y políticas. Esta ‘exportación’ habría comenzado durante la colonia con la llegada de libros europeos que traían las ideas de la ilustración y se vio reforzada con la Independencia y la influencia del liberalismo en la formación de las repúblicas. Pero su aplicación presentó problemas. Los políticos e intelectuales decimonónicos, educados en Europa o partícipes de la 'cultura occidental' no comprendían cómo las finas elaboraciones ideológicas y políticas pensadas para una sociedad burguesa en ascenso no resultaban en sus propios países divididos en castas o grupos raciales. Pero más que pertenecer a escuelas filosóficas estrictamente determinadas y acotadas, la actitud general de los intelectuales y políticos liberales del siglo XIX fue la de adscribir a ideas políticas que tenían que ver con la secularización de la sociedad, supremacía del Estado sobre la Iglesia, defensa de las libertades políticas y la educación laica.

Con la llegada del positivismo a mediados de siglo esta situación cambió. La adscripción a las ideas de Comte provocó cierta rigidez en las ‘actitudes intelectuales' de los conversos a esa ideología. Pero, en líneas generales, el liberalismo aportó las bases políticas para el orde- 
namiento de la sociedad y el positivismo influyó fundamentalmente en la estructuración del conocimiento de determinados espacios educacionales y universitarios.

Esta rigidez interpretativa cambió a fines del siglo XIX. La intelectualidad de clase media, en su mayoría formada bajo los mismos modelos liberales y positivistas, se empezó a separar del dominio político y cultural de las oligarquías latinoamericanas, generando lecturas propias de la realidad social y cultivando una actitud ecléctica y heterodoxa. El fin de siglo implicó así el desprestigio del liberalismo y el positivismo como discursos organizadores de la sociedad, lo que a su vez trajo un cambio de las ideologías y de las opciones intelectuales que sustentaron los nuevos grupos sociales.

En este trabajo queremos analizar la influencia de Nietzsche en algunos intelectuales de la izquierda latinoamericana de principios de siglo, tratando de indagar qué tan profunda e importante pudo haber sido para la formación de sus reflexiones críticas respecto de la sociedad que querían cambiar y sus propias actitudes intelectuales. Queremos ver cómo estos sujetos, de diferentes orígenes sociales e intelectuales, articularon la evidente influencia nietzscheana con la elaboración filosófica, cultural y política que realizaron.

El presente artículo esta dividido en cuatro secciones. La primera aborda las traducciones que se difundieron en América Latina en la época, tratando de responder a la interrogante de cuáles fueron los problemas de la fidelidad con que las ideas de Nietzsche llegaron a esta región. La segunda analiza la influencia en un intelectual argentino vinculado al movimiento de la Reforma de 1918 en Córdoba. La tercera trata acerca de la influencia en José Carlos Mariátegui y el 'marxismo latinoamericano'. Finalmente, abordamos el caso chileno que tiene diferencias con los anteriores; en ese país hemos podido detectar una multiplicidad de lectores nietzscheanos, especialmente anarquistas, y las ideas del alemán vinculadas al movimiento estudiantil y a la revista Claridad. Debemos advertir que, por razones de espacio y tiempo, hemos dejado de lado algunos lectores de Nietzsche, como el cubano Julio Antonio Mella, el argentino José Ingenieros, los poetas 
FABIO MORAGA

chilenos Vicente Huidobro y Pablo de Rokha, y, aunque no son propiamente izquierdistas, los mexicanos Antonio Caso y José Vasconcelos.

\section{El problema de las traducciones}

¿Qué textos y, especialmente, qué traducciones de Nietzsche leyeron nuestros intelectuales? Sin bien muchos de ellos dominaban otros idiomas a la perfección, la cultura francesa gozó en el siglo XIX de un incuestionable prestigio entre las elites latinoamericanas. Fue la lengua de las ideas de la revolución francesa, leídas profusamente por nuestros prohombres liberales; la llegada de las obras de Comte reforzaron ese prestigio a grado tal que en la Escuela Nacional Preparatoria, formadora de la generación mexicana del Ateneo, fue obligatorio en sus programas. También el poeta Vicente Huidobro era culturalmente más francés que chileno y nunca se ha aclarado si su 'creacionismo' fue de origen latinoamericano o galo. Definitivamente el idioma de la ciencia, la cultura y la poesía era el francés, pero ¿cómo llegaron esas traducciones y cuáles son los problemas a que nos enfrentan en cuanto a la fidelidad de la transmisión de las ideas nietzscheanas al español? ¿Cuáles fueron leídas por nuestros intelectuales y cómo influyeron en la apreciación que tuvieron del autor alemán?

Pese a las dificultades que podría haber presentado la divulgación de textos de Nietzsche en América Latina, sus obras se difundieron tempranamente. En 1901, apenas un año después de su muerte, la obra del alemán estaba siendo recibida por el público chileno. Gonzalo Sobejano en un extenso estudio ${ }^{1}$ establece que la primera traducción de una obra de Nietzsche al castellano fue hecha en el mismo año de su muerte por la editorial La España Moderna y correspondió a Así hablaba Zaratustra (el texto tuvo una reimpresión en 1906); algunos sospecharon que el traductor, 'Juan Fernández', era Miguel de Unamuno, buen conocedor y traductor del inglés y el alemán, pero Sobejano se

\footnotetext{
${ }^{1}$ Gonzalo Sobejano, Nietzsche en España,
} 


\section{NIETZSCHE Y LA IZQUIERDA}

inclina por el intelectual krausista José de Caso y Blanco. La misma editora tradujo al año siguiente Más allá del bien y el mal; La genealogía de la moral y Humano demasiado humano, todas sin mencionar al traductor y sin prólogo ni notas. Este último año un tal Luciano de la Mantua tradujo Aurora y en 1904, un volumen titulado Últimos opúsculos que contenía El Caso Wagner; Nietzsche contra Wagner; El ocaso de los ídolos y El Anticristo. El mismo traductor se encargo de La gaya ciencia en 1905 o 6, agregando un prólogo. Edmundo GonzálezBlanco tradujo, también para La España Moderna, El viajero y su sombra.

La editorial anarquista ‘F. Sempere y compañía, Editores’, de Valencia, hizo una importante labor de difusión de las obras de Nietzsche, tanto en España como en América Latina, entre 1906 y 1910. Realizaron varias reediciones baratas para un público compuesto en gran número por militantes o simpatizantes de organizaciones ácratas y de izquierda. De las obras del filósofo alemán Sempere publicó, Así hablaba Zaratustra; La genealogía de la moral; El Anticristo; La gaya ciencia; Humano, demasiado humano; El origen de la tragedia; Aurora; El crepúsculo de los ídolos; Más allá del bien y el mal; El viajero y su sombra; Ecce homo; El caso Wagner; Nietzsche contra Wagner. Estas ediciones hechas en su mayoría copiando otras ya trasladadas al castellano, en general abrevian impúdicamente cambiando incluso el sentido de muchas frases y sentencias.

Un problema más complicado y central, tanto para lectores latinoamericanos como europeos, es el que nos plantea su último libro. En "Problemas de El Anticristo de Friedrich Nietzsche", 2 Andrés Sánchez Pascual demuestra que todas las traducciones de esta obra al castellano, entre 1902 y 1970, contienen innumerables falsificaciones y errores. En un detallado análisis este traductor español muestra cómo la totalidad de los textos que no alcanzó a publicar en vida fueron víctimas de mutilaciones y 'correcciones’ tendientes a tergiversar el sentido de

2 Andrés Sánchez Pascual, "Problemas del Anticristo de Friedrich Nietzsche”, Revista de Occidente, $\mathrm{n}^{\circ}$ 125-126, julio-agosto de 1973, p. 209. 


\section{FABIO MORAGA}

sus escritos. Sólo los publicados entre el año 1871, en que editara El nacimiento de la tragedia, y 1888 en que diera a la prensa El crepúsculo de los ídolos, son dignos de fiar, el resto no corrió la misma suerte: "Aquí sí, aquí todo, absolutamente todo ha sido manipulado y falsificado”, sostiene. Entre estos textos, se encuentran, por un lado, El Anticristo, Ecce Homo, Nietzsche contra Wagner, y Ditirambos de Dionisio, y por otro las anotaciones, apuntes, planes, aforismos, no preparados para la impresión por Nietzsche, y que han llegado hasta nosotros en cuadernos de notas y hojas sueltas, ha sido modificado, constituyendo "un escándalo sin precedentes en la historia de la cultura europea”.

Pero, ¿cuáles son las consecuencias de este escándalo para nuestro análisis? Dada la multitud de falsificaciones, cabe la posibilidad de que los lectores latinoamericanos nunca hayan conocido el verdadero alcance de la última y fundamental obra de Nietzsche ni de la mayoría de su producción, y que sin tergivesar sus ideas hubieran cambiado la opinión de sus receptores de haberlas conocido.

La primera traducción de El Anticristo al castellano fue publicada en Madrid en 1902 por Bernardo Rodríguez Serra. Al parecer fue efectuada sobre la segunda edición alemana de 1899, pero Sobejano sospecha que está hecha del francés y es, a juicio de Sánchez Pascual, 'la más imperfecta’. En la portada se leía: “Federico Nietzsche/El Anticristo/Ensayo de una transmutación de todos los valores/Traducción directa del alemán/por/ Luis Jiménez García de la Luna/Licenciado en filosofía y letras/Madrid/Bernardo R. Serra, Editor [...]”.

La segunda, de 1906 o 7, hecha por La España Moderna, contiene cuatro textos: El caso Wagner; Nietzsche contra Wagner; El ocaso de los ídolos y El Anticristo. El traductor, Luciano de Mantua, incluye una ‘nota a la presente edición’ informada, pero según Sánchez Pascual la tarea está 'llena de despropósitos', dado que, por ejemplo, modifica el título original de la versión definitiva con la titulación: “El Anticristo/Primer libro de la voluntad de la potencia/Ensayo de una transmutación de todos los valores/Prólogo”. La traducción, hecha de la segunda edición de la obra en alemán, de 1907, reprodujo una mo- 
dificación en la que no incurren otras ediciones: en la página 197 se incluye una nueva portada con el subtítulo "Ensayo de una crítica del cristianismo".

La principales consideraciones sobre las falsificaciones de las ediciones alemanas que Sánchez Pascual denuncia se le hicieron a El Anticristo, son las siguientes. Primero, el cambio en el subtítulo 'maldición sobre el cristianismo’ por la palabra más neutral ‘crítica’ o el agregado ‘transmutación de todos los valores’. Segundo, la discusión del subtítulo no es cuestión menor pues indica la evolución intelectual de los últimos momentos de lucidez de Nietzsche, cuando el filósofo que había pensado titular la obra ‘crítica’ o ‘transvaloración’ prefiere ‘maldición’. Pero ninguna de las portadas que el autor preparó fueron reproducidas por la dueña del archivo Nietzsche, su hermana. Tercero, estas tergiversaciones tenían como propósito atenuar las opiniones del filósofo contra el cristianismo, ya en la segunda edición alemana de 1899 (que se utilizó para la edición primera española de la Editorial Rodríguez Serra), se cambió el prólogo de El Anticristo diciendo que era la introducción a La voluntad de poder. Según Sánchez Pascual: "uno de los más grandes fraudes literarios de este siglo, hace aquí su primera aparición pública”. Similares propósitos tuvo la cuarta edición alemana denominada "Taschen-Ausgabe" sobre la que se tradujo la segunda edición castellana de 1906 o 7.

En resumen, ‘transvaloración de todos los valores' fue el proyecto de una obra convertida en subtítulo, luego sustituido por 'maldición sobre el cristianismo', que los lectores castellanos no conocieron hasta 1970. Y respecto a la 'voluntad de poder', si bien Nietzsche también la bosquejó como obra, anunciándola en dos oportunidades, luego la desechó. Enloqueció antes. Sobejano finaliza su prolija revisión de las traducciones castellanas sentenciando:

Cualesquiera que sean los defectos de las traducciones españolas, menester es convenir que no fueron tardas ni escasas: salieron a la luz temprano, en abundancia y con continuidad. Así, pudieron proporcionar a los lectores españoles un cono- 


\section{FABIO MORAGA}

cimiento bastante completo y veloz, aunque en general poco depurado, del discutido filósofo. ${ }^{3}$

Concluyendo, estas ediciones desde la primera de 1895 fueron vertidas desde el alemán, mal podían leer entonces las ‘auténticas’ ideas de Nietzsche los latinoamericanos si las falsificaciones introducidas por la ‘dueña’ de los manuscritos ya aparecían en sus diciciones originales. Hecha la salvedad, reformulamos la cuestión: ¿Qué consecuencias tuvo la lectura del filósofo en los lectores latinoamericanos?

\section{Nietzsche en Argentina: el germen de toda rebeldía}

Aunque fue José Ingenieros quien inauguró las lecturas de Nietzsche en Argentina, el joven abogado Deodoro Roca (1890-1942), fue uno de los lectores más aplicados. Nacido en Córdoba, en el seno de una familia oligárquica, fue director del Museo Provincial Sobremonte, cargo que debió dejar por su adhesión a las luchas estudiantiles. Ejerció la cátedra de Filosofía General en la Facultad de Derecho en la Universidad de Córdoba y fue el redactor del Manifiesto Liminar, que los estudiantes reformistas adoptaron y difundieron como su programa en junio de 1918. Alrededor de 1936 dirigió la revista Flecha de la que editó diecisiete números durante dos años.

Un estudio reciente acerca de su vida intelectual, que además reúne una importante antología, destaca la figura de Roca por su heterodoxia. En Deodoro Roca, el hereje, ${ }^{4}$ Néstor Kohan sostiene que este intelectual reformista, injustamente olvidado por la historiografía oficial argentina, era un pensador 'herético’ hacia las ideologías de su época. Éste habría adaptado, de las principales corrientes reformistas cordobesas, un tono iconoclasta y anticlerical y un marxismo "completamente despojado de su caparazón ilustrado y economicista” incorporando el

${ }^{3}$ Sobejano, op. cit., p.

${ }^{4}$ Néstor Kohan, Deodoro Roca, el hereje, 1999, Buenos Aires, Biblos. 


\section{NIETZSCHE Y LA IZQUIERDA}

romanticismo "antiburgués libertario, culturalista, juvenilista y humanista”, cuya fuente principal fue Nietzsche.

No sabemos exactamente cuáles fueron las traducciones de la obra de Nietzsche leídas por Roca, que entendía el francés. Hay un desfase temporal entre la lectura y los primeros escritos que el intelectual cordobés le dedicó, pero desde 1915 era parte de sus lecturas habituales. Por ejemplo, el Manifiesto Liminar, publicado en una edición extraordinaria de La Gaceta Universitaria hace una alusión indirecta a El Anticristo: “¡Curiosa religión que enseña a menospreciar el honor y deprimir la personalidad! ¡Religión para vencidos o para esclavos!”5

Cuando triunfó el movimiento reformista, Roca asumió la cátedra de Filosofía General en la Facultad de Derecho y Ciencias Sociales reformulando su plan de estudios. En él enfatizaba la filosofía del siglo XIX en detrimento de la escolástica que antes se enseñaba en la universidad, integrando la psicología y en particular a Wundt, Nietzsche y Williams James, el 'neocriticismo francés', las tendencias filosóficas, místicas y metafísicas, la escuela de Marburgo, la teoría de los valores y finalmente a Bergson y Croce.

El joven abogado cordobés dedicó al menos cinco escritos al alemán. El primero de ellos, Impulso y contención de 1930, reflexiona acerca de la búsqueda de la felicidad por el ser humano y gira en torno a $E l$ nacimiento de la tragedia. Roca parte del aforismo nietzscheano que enfrenta lo apolíneo y lo dionisíaco: "el hombre prefiere siempre la embriaguez a la nutrición”, para plantear que comúnmente se piensa que la felicidad se logra por medio de la educación y la cultura, idea que remonta a Rousseau. Sosteniendo que pese a ser una creación humana, el hombre actual se siente atrapado por ella, por lo que la respuesta común a este dilema es siempre negativa, pues la cultura actual ha dejado la meta de la felicidad en pos de otros objetivos, como la tecnocratización de la sociedad. Esta infelicidad se debía al

\footnotetext{
${ }^{5}$ En particular en el parágrafo 21 de El Anticristo, Nietzsche sostiene la
} idea del cristianismo como religión de oprimidos. 
FABIO MORAGA

abandono de la verdadera naturaleza humana, la heterodoxia de su cultura:

La vuelta a la naturaleza, el culto al deporte, la inmersión en el placer inmediato y momentáneo, la sinceridad cínica, la violencia anárquica, la locura incluso, y tantas otras expresiones de la heterodoxia contemporánea definen la pugna exasperada entre el mundo de la cultura y el afán de felicidad, característico de nuestra época. Todas las herejías anticulturales proceden de esa fuente. $\mathrm{O}$ de esa herida. ${ }^{6}$

Para Roca la heterodoxia, el concepto central que propone en este texto, representa anhelos humanos que, citando a Freud, han quedado reprimidos de la 'normalidad'. La solución es que la cultura retome esos impulsos reprimidos y los incluya en su ámbito en vez de pretender aniquilarlos o expulsarlos. El artículo termina con el proyecto de intervención social: escribir acerca de la forma cómo estos elementos se deben incluir en el programa cultural.

Nietzsche en Italia es una recensión de un libro del francés Guy de Portualés, ${ }^{7}$ comentando un viaje que el alemán hiciera en 1876, siendo un joven profesor. Publicada en 1930, si bien no tiene mayor profundidad conceptual, trasluce algunas opiniones interesantes para el proyecto político del cordobés. Define al Zaratustra, cuyo manuscrito el alemán llevaba en su maleta de viaje, como "el larvado pensamiento filosófico contemporáneo, los gérmenes de toda rebeldía actual”. Roca, rescata otros aspectos, como el significado de su pensamiento en la actualidad, que implicaría acabar con el miedo a la muerte y sembrar en la conciencia de los contemporáneos la noción de ‘suave melancolía' al "no poder vivir lo bastante como para conocer las maravillas del pensamiento y del mundo”. Zaratustra había tomado posesión de las inteligencias contemporáneas e implicaba, según Roca, un nuevo sen-

${ }^{6}$ Deodoro Roca, “Impulso y contención”, El País, 21 de diciembre de 1930, en Kohan, op. cit., p. 134.

${ }^{7}$ Guy de Portuales, Nietzsche en Italie, 1929, París, Bernard Grasset. 
tido de la vida, una vitalidad especial el hombre antes que animal sabio o animal religioso ‘es un animal que vive’ y la muerte es la que le otorga esa conciencia vital. Todo esto, pese a, y precisamente por, la enfermedad y la conciencia de la muerte que tenía Nietzsche.

El siguiente texto, La meta del superhombre, al parecer permaneció inédito en el archivo de su hermana Cristina. Escrito en 1931, plantea una fuerte identificación con la ética nietzscheana. Parte señalando que las ‘esencias nietzscheanas’ habían permeado la filosofía contemporánea produciendo una gran cantidad de seguidores, que no formaron una escuela sino que más bien siguieron las actitudes del filósofo alemán y hoy ‘toman aire en las colinas del pensamiento’. Mientras que para sus detractores, que sí se reunían, el pensador:

es de los que derriban ese tinglado ético que coloca en una dicha presente -o futura- todo el sentido de la vida. Este concepto de la existencia humana no puede decidir su valorización, estructurar la jerarquía. No puede ser valorado con miras hacia un eterno epílogo feliz, incontrolable. Sería explicar una vida por lo que la destruye. Sería como afirmarla en su negación.

El texto continúa con una valoración del concepto de superhombre. De acuerdo con el filósofo, lo único que puede proporcionar una valoración verdadera es la propia 'grandeza interior'; cuando la sociedad pudiese producir una gran cantidad de hombres superiores, entonces alcanzaría su 'legítima cumbre'. Roca rescata las críticas de Nietzsche a los hombres mediocres y a los que tratan de nivelar todo a su propia talla:

Si todos los hombres son otras tantas voluntades de afirmación y dominio -aun comenzando por los que afirman su misma esclavitud- el valor supremo vital radicará en aquellos cuya voluntad de poder sea más fuerte. Por eso el ‘superhombre’ es para Nietzsche la corona del mundo. 


\section{FABIO MORAGA}

Según Roca, a esta idea tan controvertida de la obra nietzscheana se le falseó su verdadera implicancia considerándolo una muestra de soberbia. Así rescata lo que para él es el verdadero concepto de superhombre:

esa grandeza se mide por las responsabilidades que arrastra (...) Por eso no es posible creer en la grandeza de un hombre a quien sus opiniones y sus actos no lo sitúan frente al supremo riesgo vital. ¿Es esto soberbia? No. Es afán de exaltar al hombre, de hacerle dar el máximo de rendimiento espiritual. Y de despojarlo de toda farsa. Es dejarlo solo y desnudo ante su propio -inapelable- tribunal.

Juventud y servidumbre, el más 'político’ de los textos nietzscheanos escritos por Roca, ${ }^{8}$ es un breve manifiesto en que critica a los jóvenes católicos, sin mencionarlos directamente. Comienza sosteniendo que se puede ser joven, pero tener una 'mente atávica', y se puede ser viejo y anheloso de una vida mejor. A los primeros les critica su conservadurismo 'que se cierra a toda idea renovadora'. El conjunto del texto gira en torno a las actitudes que se deben tener:

Toda revolución, todo progreso, es, al cabo, un desplazamiento de interés. Requiérese, además, cierta actitud heroica para la soledad. Nietzsche medía el valor de cada individuo por la soledad que pudiese soportar. Vale decir, por la distancia a la cual el espíritu -valeroso- es capaz de colocarse con relación a la muchedumbre, siempre expresiva de los 'intereses creados'.

Continúa sosteniendo que aquellos que, basados en lo religioso y lo espiritual, sostienen que van a hacer de sus ideas la base para regir el orden moral y material del mundo, al mismo tiempo preconizan los medios más groseros para gobernar y organizar el orden. Roca está

${ }^{8}$ Roca, “Juventud y servidumbre”, El País, 14 de junio de 1931. 
reaccionando acá al avance del fascismo en los sectores juveniles de la Iglesia Católica, que encontraban en la fuerza la jerarquía suprema:

Ahí está la raíz de su característico ademán ‘combativo’, no persuasivo, frente a las otras ideas. Las 'persiguen’ sañudamente, en cuanto pueden. Desconocen la virtud de la tolerancia. Atropellan, destemplados y fieros, derechos y libertades. Como si estos derechos y libertades fueran irrealizables y nada significaran. Ningún rastro, en lo político de esa luz que -en lo religioso- es la persuasión.

En El drama social de la universidad, publicado en 1936, que bien podría titularse Marx, Nietzsche y la reforma universitaria, Roca critica a la universidad argentina de la época calificándola con duros términos: "un remedo, una imitación, en algunos aspectos deliciosamente cómica”. Pero esta crítica arranca desde una comparación de los pensamientos de Marx y Nietzsche, aquellos 'obstinados y terribles negadores', a propósito de una balance histórico de la universidad burguesa del siglo XIX. Ésta, según él, había logrado su máximo desarrollo en esa centuria a través de los valores de la clase que la sustentó: ciencia, técnica, enseñanza del Estado, así "se movía el ideal humanitario que Humboldt bien definiera: educación estético humanística. El Estadofuerza era también Estado-idea. Su concepción del hombre y del universo era entregada a las universidades para su propaganda y realización”.

Pero este desarrollo alcanzado se estancó, pues se abandonaron los ideales originales cuando el nacionalismo sustituyó al humanismo cosmopolita, sin embargo la institución siguió su rumbo inicial. Es aquí donde Roca introduce la crítica de sus dos 'terribles negadores'. Aunque reconoce que provenían de tradiciones intelectuales disímiles, por diversas concepciones filosóficas y morales, rescata de Marx su pensamiento social, y de Nietzsche sostiene que sus concepciones estaban movidas: "en nombre de una cultura que tenía que convertirse en sangre y en gesto”. Según Roca, este pensamiento habría sido tomado por un grupo para superar el nacionalismo, mientras los marxistas 


\section{FABIO MORAGA}

plantearon la obsolescencia de los ideales culturales de la burguesía. Así, el aporte de los filósofos alemanes operó un cambio en la cultura:

Se empezó a hablar del hombre integral, del individualismo de la cultura, de la soledad creadora. En este punto preciso, llegó la guerra, y luego la 'crisis' de la posguerra, que en un sentido moral no fue crisis, sino otro momento histórico al que ha seguido un cambio fundamental en la conciencia de la época. Después, la Técnica. Y con ella el olvido de los ideales de la personalidad. El individuo se ha disuelto en función. Ser, es ser objetivo. Ser es ser en relación a unas cosas y poder después convertirlas en dinero. Y esto, por último, significa poder, o posibilidad de vivir. Y éste es el problema que señala la división de dos épocas.

El ejercicio que efectúa Roca es complejo. Primero hace un balance histórico del fenómeno universitario europeo; después utiliza los aportes filosóficos e interpretativos de dos pensadores tradicionalmente puestos en contradicción por los exégetas para interpretar un fenómeno de su tiempo: la tecnificación de las relaciones sociales. Finalmente realiza una interpretación del devenir cultural occidental: una época dominada por la burguesía dividida en dos fases: una culturalmente cosmopolita, con una universidad enfocada en esa dirección, otra de predominio de las ideas nacionalistas, pero con una universidad enfocada en el camino original. Luego se puede distinguir una etapa que niega esa hegemonía, expresada en la influencia de las ideas nietzscheanomarxistas, que "implicaba un cambio fundamental en la conciencia de la época” que podemos definir como individualista. Finalmente, Roca plantea su tiempo presente como una etapa 'tecnocrática', en que la característica es la destrucción del individuo construido en la etapa anterior. La tecnocratización, y la conciencia social que ésta produce, junto a la proletarización de los grupos sociales medios, influyó en la universidad disolviendo sus antiguos ideales. Este fenómeno general lo aplica al caso argentino, sosteniendo que la Reforma había 
sido un movimiento marcado por un 'disconformismo radical y total' contra la universidad ‘pretenciosa y estéril’ y hoy, pese a esta rebelión, la gran producción científica se resumía en 'apuntes'.

El movimiento de la Reforma, emprendido para disolver la supremacía del profesor sobre el alumno, había tratado de expandirse a la educación en su totalidad y luego a la sociedad, seguía padeciendo los mismos males iniciales. Pese a este balance casi pesimista, Roca rescata la conciencia de crítica social que había aportado y la certeza de que no se puede reformar la universidad sin reformar la estructura del Estado.

Roca termina planteando las falencias del movimiento al que había contribuido protagónicamente: a la Reforma y a lo 'social' había que agregar el hombre (el individuo), pues no todo se resolvería en lo político, sino también en lo cultural: el ‘problema político’ se tornaba inseparable del 'problema de la cultura'. Este había sido un aspecto olvidado en 1918 y que en ese momento había que abordar.

\section{Nietzsche en el Perú: más que pensamiento, acción y combate}

Nietzsche tuvo en el Perú la recepción de José Carlos Mariátegui, uno de los ideólogos más famosos y discutidos de la izquierda latinoamericana. Mariátegui nació en Moquehua en 1896 y tras una corta y agitada existencia murió en Lima en 1930. Su pensamiento ha sido fruto de arduas discusiones y de prolongadas polémicas intelectuales e ideológicas. Aunque prolífico, no perteneció al mundo académico, su preocupación fundamental fue la formación de un campo cultural donde las ideas del socialismo pudieran sentar las bases de un cambio profundo en el Perú. En su biografía intelectual se distinguen dos etapas claramente diferenciadas. La primera, poética y bohemia, que él mismo llamó su 'edad de piedra', se prolongó hasta 1919, año en que por disposición del presidente Leguía debió salir exiliado a Europa. Ahí estuvo radicado en Italia donde tomó contacto con todas las tendencias 


\section{FABIO MORAGA}

culturales e ideológicas de la postguerra convirtiéndose, como él mismo lo señalara, en un 'marxista convicto y confeso'.

Si bien su estudio académico se inició recién en 1960, cuando sus parientes publicaron sus obras completas, fue sólo en 1994, año de su centenario, que se enfrentó de manera más profunda el análisis y la difusión de su pensamiento. Durante mucho tiempo la reflexión política e ideológica y la labor cultural que realizó en el Perú fue escondida, tergiversada y a veces anatematizada, por dos tradiciones políticas latinoamericanas: el populismo aprista y el marxismo ortodoxo. Militante de la Alianza Popular Revolucionaria de América Latina, APRA, fue uno de sus fundadores y líderes principales junto a Haya de la Torre; cuando éste intentó convertirla en partido político, se dividió con un grupo de sus correligionarios peruanos y fundó el Partido Socialista del Perú, PSP. Al margen mantuvo una serie de publicaciones de carácter intelectual e ideológico, cuyo eje central era una profunda, heterodoxa y multifacética discusión cultural, entre éstas, Amauta y Mundial fueron fundamentales. En 1928 publicó su trabajo más connotado, Siete ensayos de interpretación de la realidad peruana, considerado el texto fundacional del 'marxismo latinoamericano'.

El movimiento teórico que efectuó en sus análisis de la realidad reúne una serie de pensadores y tradiciones de origen muy diverso e incluso opuesto. La relación con Nietzsche ha sido obviada pese a la reciente multiplicación de interpretaciones y discusiones sobre su pensamiento. Por ejemplo, Robert Paris, al analizar los orígenes del marxismo latinoamericano, al igual que otros ha tratado de responder a las acusaciones del ‘sorelianismo’ de Mariátegui, hechas por la izquierda ortodoxa, reparando, de pasada, en que también leía al alemán:

No debe asombrar, pues, que en una época en que Mussolini reivindica a Nietzsche, Williams James y Georges Sorel en una entrevista publicada en el periódico Le Temps, Mariátegui inicie sus Siete ensayos (...) citando a Nietzsche y no a Marx. Por otra parte, ¿es que durante la misma época Nietzsche no era invocado por el dirigente comunista cubano Julio Antonio 


\section{NIETZSCHE Y LA IZQUIERDA}

Mella? Tampoco debe sorprender si en un marxismo ya interpretado por Sorel, Mariátegui intenta una vez más integrar el pragmatismo de James, el bergsonismo y el psicoanálisis. ${ }^{9}$

A pesar de la referencia volátil a Nietzsche, Paris centrado en el ‘sorelianismo’, no explica el ‘nietzscheanismo’ de Mariátegui. Defensores y retractores se han centrado en la discusión acerca de la influencia en el peruano de un pensador como Sorel, cuyas propuestas tenían que ver más con la política contingente, pero no han reparado en la importancia de Nietzsche en la reflexión teórica de sus Siete ensayos.

Un artículo de Ofelia Schutte, profesora del Departamento de Filosofía de la Universidad de Florida, es quizá el único trabajo que explora la influencia del alemán y su recepción en el marxismo latinoamericano. Schutte, parte de trabajos similares que estudian la influencia de Nietzsche en los izquierdistas alemanes y rusos de comienzos de siglo, entre ellos Lunacharsky, que formaron lo que se denomina 'marxismo nietzscheano'. ${ }^{10}$

¿De qué manera Mariátegui integra en su pensamiento político e ideológico a Nietzsche? Schutte ha propuesto la insinuante tesis de que el peruano estaba consciente de lo polémico que resultaba para el marxismo europeo la aceptación de las ideas de Nietzsche. Sin embargo, creemos que su actitud heterodoxa y ecléctica lo llevó a integrar en su reflexión no sólo el pensamiento del alemán sino también de otros aportes que resultaron controvertidos para la izquierda comunista agrupada en la Tercera Internacional, desatando con ello una fuerte polémica desde fines de la Segunda guerra mundial. Esa izquierda lo acusó de 'confusionista' por sostener que en América Latina los aliados del proletariado en la lucha por el socialismo eran el indígena y el

${ }^{9}$ Robert Paris, “El marxismo de Mariátegui”, en José Aricó, Mariátegui y los orígenes del marxismo latinoamericano, 1978, México, Siglo XXI.

${ }^{10}$ Ofelia Schutte, "Nietzsche, Mariátegui y el socialismo: ¿Un caso de ‘marxismo nietzscheano' en el Perú?”, Anuario mariateguiano, 1992, n 4, Lima, Amauta. 


\section{FABIO MORAGA}

campesinado, tesis que sostuvo en dos encuentros de la Internacional Comunista realizados en Montevideo, en 1930, próximo a morir por una enfermedad que lo mantenía lisiado.

Junto con Marx, los principales autores que Mariátegui articuló en su reflexión propiamente marxista, fueron Croce, Bergson y Sorel. Estos dos últimos rescataban, contra el racionalismo y el cientificismo de la época el valor de la irracionalidad y el mito como substratos movilizadores de la sociedad de principios de siglo; pero la inclusión de Nietzsche fue menos explícita. En 1928 escribió en la 'advertencia' que precedía a sus Siete ensayos, que seguía el derrotero de Nietzsche en el parágrafo "Del leer y el escribir” de Así hablaba Zaratustra:

Como la Escena contemporánea no es éste, pues, un libro orgánico. Mejor así. Mi trabajo se desenvuelve según el querer de Nietzsche, que no amaba al autor contraído a la producción intencional, deliberada, de un libro, sino aquel cuyos pensamientos formaban un libro espontánea e inadvertidamente. Muchos proyectos de libros visitan mi vigilia; pero sé por anticipado que sólo realizaré los que un imperioso mandato vital me ordene. Mi pensamiento y mi vida constituyen una sola cosa, un único proceso. Y si algún mérito espero y reclamo que me sea reconocido es el de -también conforme a un principio de Nietzsche- meter toda mi sangre en mis ideas. ${ }^{11}$

Schutte sugiere que a su regreso al Perú, y por lo polémico que resultaba la aceptación de las ideas nietzscheanas, "Mariátegui siguió la sana regla de incorporar las ideas de Nietzsche en un argumento marxista sin nombrar específicamente al filósofo alemán”. Sin embargo, pensamos que esta autocensura no existió en la reflexión mariateguiana, dada la integración explícita y enfática de otros autores que, si bien en ese momento no estaban estigmatizados por la ortodoxia comunista, al menos resultaban 'extraños'. La inclusión de Nietzsche

${ }^{11}$ Mariátegui, Siete ensayos de interpretación de la realidad peruana, 1959, Lima, Amatua, p. 7. 


\section{NIETZSCHE Y LA IZQUIERDA}

en una reflexión marxista es problemática para los marxistas contemporáneos y no para los que vivieron y reflexionaron antes de la Segunda guerra.

Por otra parte, debe recordarse que en ese momento al peruano militaba en el APRA que no estaba afiliado a la Internacional Comunista y que la polémica suscitada en torno al ‘confusionismo’ de Mariátegui es posterior a la etapa en que escribe influenciado por Nietzsche e incluso, posterior a su muerte.

Descartada así la tesis de 'ocultamiento' del 'nietzscheanismo mariateguiano’, podemos centrarnos en la influencia del filósofo alemán. Schutte repara en los textos de Mariátegui Dos concepciones de la vida, El hombre y el mito y La lucha final, publicados en Mundial entre enero y marzo de 1925, pero no señala sus elementos nietzschianos específicos. Se limita a decir que utilizó 'temas importantes' de El nacimiento de la Tragedia y Sobre la ventaja y la desventaja de la historia para la vida.

El mito fue extensamente trabajado por Nietzsche, Bergson y Sorel. La tesis mariateguiana que une sendos textos es la de la necesidad del mito que tiene el 'yo profundo', y se inscriben en la 'descontrucción' que hacen Bergson y Sorel de los valores burgueses de la época. En su análisis de la obsolescencia de la ética burguesa en la posguerra, el peruano sentencia: "La vida, más que pensamiento, quiere ser hoy acción, esto es combate. El hombre contemporáneo tiene necesidad de fe. Y la única fe, que puede ocupar su yo profundo, es una fe combativa. No volverán, quién sabe hasta cuando, los tiempos de vivir con dulzura."12

Estas frases corresponden a Dos concepciones de la vida. En El hombre y el mito, escrito una semana después, vuelve sobre el eje de su reflexión: "Ni la razón ni la ciencia pueden satisfacer toda la necesidad de infinito que hay en el hombre. La propia razón se ha encargado de demostrar a los hombres que ella no les basta. Que únicamente el mito posee la preciosa virtud de llenar su yo profundo.”

\footnotetext{
${ }^{12}$ Mariátegui, Mundial, Lima, 6 de enero de 1925.
} 


\section{FABIO MORAGA}

Si bien Nietzsche está presente ‘detrás’ de las hipótesis y movimientos teóricos que Mariátegui efectúa, los textos están más directamente influidos por Sorel y Bergson. Donde aparece un tema innegablemente nietzscheano es en La lucha final, aquí revela una concepción de la historia hereditaria de Nietzsche, pero no copia ortodoxa respecto al 'eterno retorno' y a la presencia cíclica del mito de la lucha final:

Se trata, efectivamente, de la lucha final de una época y de una clase. El progreso -o el proceso humano-se cumple por etapas. Por consiguiente, la humanidad tiene perennemente la necesidad de sentirse próxima a una meta. [...] El mesiánico milenio no vendrá nunca. El hombre llega para partir de nuevo. No puede, sin embargo, prescindir de la creencia que la nueva jornada es la jornada definitiva. Ninguna revolución prevé la revolución que vendrá después, aunque en la entraña porte su germen.

Acá rompe la idea del eterno retorno, recalcando que ‘el mesiánico milenio no vendrá nunca’. Pese a reflexionar acerca del pasado indígena de su país, su concepción de la historia es progresista y no cíclica: 'el hombre llega para partir de nuevo', este hombre es el 'sujeto de la historia', su protagonista.

Otro de los 'usos' que hace Mariátegui de Nietzsche tiene que ver con una 'actitud intelectual' que aclara en la citada 'advertencia', y que no debe subestimarse, dado que actitud y pensamiento van unidos en la reflexión mariateguiana. Una lectura atenta de 'El proceso de la literatura’, la clave de los Siete ensayos, revela su concepción nietzcheana que guía todo el libro:

Declaro sin escrúpulo que traigo a la exégesis literaria todas mis pasiones e ideas políticas, aunque, dado el descrédito y degeneración de este vocablo en el lenguaje corriente, debo agregar que la política en mí es filosofía y religión. Pero esto no quiere decir que considere el fenómeno literario o artístico desde 
puntos de vista extraestéticos, sino que mi concepción estética se unimisma, en la intimidad de mi conciencia, con mis concepciones morales, políticas y religiosas, y que, si dejar de ser una concepción estrictamente estética, no puede operar en forma independiente. $^{13}$

De esta manera, Mariátegui integraba el hilo conductor nietzscheano que había declarado al decir: "Mi pensamiento y mi vida constituyen una sola cosa, un único proceso”, ligando estrechamente su concepción de estética a su vida y su reflexión, una traza claramente tomada del filósofo alemán y su obra.

\section{Chile: un 'vago nietzscheanismo'}

En Chile Nietzsche atrapó el interés de sectores más amplios que el de los 'intelectuales profesionales': obreros anarquistas vinculados a la intelectualidad vanguardista, inmigrantes autodidactas y estudiantes de la Federación de estudiantes de Chile, fueron sus principales lectores.

El primer rastro de una lectura del filósofo aparece en 1901 junto a un extenso poema de Guillermo Valencia publicado en la revista Pluma y Lápiz. El trabajo, titulado ‘Anarkos’, lleva un epígrafe nietzscheano. ${ }^{14}$ Un año después un breve artículo de Alberto Brandau evidencia una lectura más reposada de Nietzsche. El autor trabajó la estética nietzscheana basado en El pesimismo y Así hablaba Zaratustra. ${ }^{15}$

${ }^{13}$ Mariátegui, “El proceso de la literatura”, en Siete ensayos, p. 171.

14 "De todo lo escrito amo solamente lo que el hombre escribió con su propia sangre. Escribe con sangre y aprenderás que la sangre es espíritu de espectros. Que en la noche de sus cuevas, al ritmo de sus tristes corazones viven soñando con auroras nuevas de un sol de amor en mística alborada y, sin que llegue la mentida crisis, en medio de su mísera nidada los degüellan las ráfagas de tisis”, (Pluma y Lápiz n 27, Santiago, 2 de junio de 1901).

15 Alberto Brandau, "Nietzsche”, Pluma y Lápiz, n 84, Santiago, 6 de julio de 1902. El texto antes fue leído en El Ateneo de Santiago. 


\section{FABIO MORAGA}

Estas primeras lecturas no estuvieron exentas de polémica, como la que protagonizó Carlos V. Manríquez, desde El Ferrocarril de Santiago contestando a lectores de El Mercurio, el diario de la oligarquía plutocrática. Desconocemos datos biográficos del autor, pero por su manejo bibliográfico se puede inferir que era un gran conocedor del pensador (cita en forma precisa obras y años de publicación), correspondiente a un tipo de pensador liberal, acorde con la 'moda intelectual' de la época. ${ }^{16}$

El poeta santiaguino, José Domingo Gómez Rojas nació en 1896 y murió trágicamente en 1920, mientras estaba detenido bajo la acusación de subversión. Se hizo nietzscheano alrededor de 1913 o 1914, luego de haber editado un libro de poesía obrerista titulado Rebeldías líricas. La vida del joven vate evolucionó a la par de los profundos cambios culturales que su sociedad experimentó en la época. Gómez Rojas fue un espíritu inquieto, simultáneamente cristiano, poeta, estudiante, empleado municipal, anarquista, militante radical, nietzscheano, nihilista y militante en organizaciones obreras socialistas como la Federación Obrera de Chile, FOCH y la sección local de la Industrial Workers of the World, IWw. Pero ésas no fueron sus únicas contradicciones. Colaboraba con un periódico cristiano protestante, al mismo tiempo que escribía poesía ácrata, llegando a declararse a sí mismo una paradoja:

En mis comulgaciones yo estoy, querido hermano Con Nietzsche y con Jesús y siempre en mi camino Supe amar al profano porque ‘él’ era profano Y no odiar al divino porque ‘Él’ era divino...

‘Campanas silenciosas’ de reinos interiores que ritman en pauta psico-sentimental reflejando los raros y modernos dolores, -nietzscheanamente- más allá del bien y el mal...

${ }^{16}$ Carlos V. Manríquez S., "Federico Nietzsche”, El Ferrocarril, Santiago, 27 de diciembre de 1909. El pequeño opúsculo está dedicado a Eduardo Donoso M., de quien tampoco tenemos conocimiento. 


\section{NIETZSCHE Y LA IZQUIERDA}

¿Es bueno este artículo?

¿Es malo, muy malo?

No importa, como Nietzsche yo voy más allá del bien y el mal.

¿Cómo Nietzsche? Sí, con Nietzsche antes que Omer Emeth que va 'más allá de la Gramática’ y que Fray Apenta que va 'más allá que Soiza y Bonafoux'.

Ambos sacerdotalmente con sotanas.

Yo, como Nietzsche, y Jesús, como yo, ¿Hay contradicciones?, mejor. Como el mundo: yo soy una paradoja. $^{17}$

De este texto, importa no sólo lo que se dice sino el juego de palabras y metáforas que se entremezclan en la creación poética. No sabemos exactamente qué escritos de Nietzsche leyó Gómez Rojas, pero por sus referencias se puede deducir que sólo conoció Más allá del bien y el mal, El Anticristo y Ecce Hommo, todos editados por Sempere. El conocimiento del filósofo alemán le llegó probablemente por medio del anarquista español Ángel Fernández, que también lo relacionó con otro ácrata, el argentino Alberto Ghiraldo, director de la revista literaria Ideas y Figuras.

En torno a El Anticristo, la poesía de Gómez Rojas se volcó alternativamente hacia Cristo y el demonio como en Habla Luzbel:

Habla Luzbel y dice:

Escuchadme cielos...!

Soy Arcángel caído por mis locos anhelos.

Soy rebelde sublime y mi estirpe es divina

Y mis labios modulan formidable doctrina,

Mis palabras son fuego, mis pupilas enhiestas tienen brillo salvaje. [...]

${ }^{17}$ Citado por Fabio Moraga y Carlos Vega Delgado, José Domingo Gómez Rojas, vida y obra, 1997, Punta Arenas, Atelí, p. 23. El original apareció en Sucesos n 627 , Valparaíso, $1^{\circ}$ de octubre de 1914. 


\section{FABIO MORAGA}

El ceño de la frente de Luzbel ostentó el purpurino encono Y Dios tembló de miedo en su Augusto trono. ${ }^{18}$

Las imágenes religiosas y demoníacas en su poesía eran frecuentes, siendo la de Jesús la más común, con quien a veces se identificaba, como en 'Cristo', 'Jesús', 'Yo te perdono' y 'Locos sublimes'. Ya trastornado por las torturas a que fue sometido en la cárcel, su cristianismo se transformó en martirologio y siguiendo literalmente a Nietzsche escribió con sangre en las paredes de su celda un poema de protesta contra sus carceleros.

La llegada de la segunda década marcó un cambio profundo en la cultura chilena, cuando la nueva generación intelectual y anarquista se agrupó en el órgano de difusión de la Federación de Estudiantes de Chile, Claridad, nombre tomado del grupo francés Clarté, dirigido por Anatole France y Henrry Barbusse. A lo largo de la década de 1920 los jóvenes que sostuvieron esta revista atraídos por el individualismo anarquista, se alejaron del ‘colectivismo’ marxista, del gobierno liberal de Arturo Alessandri y de la propia Federación de Estudiantes con quienes siempre tuvieron una relación tensa. ${ }^{19}$

Fue la revista más amplia y heterodoxa que en la línea anarquista se haya publicado en Chile. Entre las muchas influencias ideológicas que pueden apreciarse de su lectura, una de las más evidentes es la de los españoles de la Generación del 98. Según Mario Góngora, el bagaje ideológico de Claridad, traslucía un:

anarquismo intelectual libertario e individualista, la afirmación de un progreso infinito, que relativiza el valor de cada una de sus etapas, nada semejante a la creencia mesiánica de

${ }^{18}$ José Domingo Gómez Rojas, Rebeldías Líricas, 1913, Santiago. Editado y prologado también por Andrés Sabella en 1940 y por Moraga y Vega, op. cit.

${ }^{19}$ Véase: Fabio Moraga, "Vanguardia, Heterodoxia y búsqueda generacional. La revista Claridad, 1920-1932”, Mapocho, n 48, Santiago, diciembre del 2000. 
una sociedad sin clases -tal vez un vago nietzscheanismo, la visión de una ilimitada mutación de valores. ${ }^{20}$

Ese ‘vago nietzscheanismo’ está patente en la Declaración de principios, redactada en junio de 1920, un mes antes que el gobierno oligárquico de Juan Luis Sanfuentes desatara una ola represiva contra trabajadores y estudiantes 'subversivos':

La Federación reconoce la constante renovación de todos los valores humanos. De acuerdo con este hecho, considera que la solución del problema social nunca podrá ser definitiva y que las soluciones transitorias a que se puede aspirar suponen una permanente crítica de las organizaciones sociales existentes. Esta crítica debe ejercerse sobre el régimen económico y la vida moral e intelectual de la nación. ${ }^{21}$

En esta declaración, fruto de la Primera Convención Estudiantil, de junio de 1920, la Federación de Estudiantes establecía un orden de prioridades para la acción.

De acuerdo con la subordinación de valores que ha establecido el Individuo a la Familia, de la Familia a la Patria y de ésta a la Humanidad, la Federación afirma que el patriotismo es un sentimiento noble que entraña el sacrificio del interés individual al colectivo. En las cuestiones internacionales someterá siempre

\footnotetext{
${ }^{20}$ Mario Góngora, Ensayo histórico sobre la noción de Estado en Chile en los siglos XIX y XX, 1990, Santiago, Ed. Universitaria, p. 116.

${ }^{21}$ Ibid. El planteamiento nietzscheano es de Umwergtung o "transvaloración” contra la acción de los sacerdotes cristianos: "nosotros mismos, nosotros los espíritus libres somos ya una 'transvaloración de todos los valores', una viviente declaración de guerra y de victoria a todos los viejos conceptos de 'verdadero' y ‘no verdadero'”, (El Anticristo, trad. De Sánchez Pascual, p. 37).
} 


\section{FABIO MORAGA}

el interés del Individuo de la Familia y de la Patria a los supremos ideales de Justicia y de Fraternidad humanas. ${ }^{22}$

De esta subordinación, inaceptable por la oligarquía porque anteponía el individuo a la familia, se derivaba una consecuencia muy importante: una ‘acción política no militante’ que rechazaba al sistema como única manera de progresar efectivamente: “...declara, finalmente, que todo verdadero progreso social implica el perfeccionamiento moral y cultural de los individuos”.

El documento en su conjunto resultó bastante polémico, tiempo después una nueva generación estudiantil, menos politizada, rechazaría su síntesis ideológica. Probablemente esta crítica se esgrimió apoyada por los sectores positivistas cercanos a la Federación. El joven abogado Carlos Vicuña Fuentes, firme defensor de la corriente positivista de la 'religión de la humanidad' publicó un folleto titulado La cuestión social ante la Federación de Estudiantes, donde discutía el principio de 'renovación constante de todos los valores', sosteniendo que:

[...] falso y anticientífico ya que admitiendo que es verdad que los conceptos humanos (o valores) de carácter filosófico o científico evolucionan; no es menos cierto que no se trastornan o modifican indefinidamente y que una vez llegados al estado positivo, ya no evolucionan más. Más aún: la evolución misma tiene una ley, una marcha determinada en virtud de la cual los principios pasan de ficticios a abstractos y de abstractos a positivos, de absolutos a relativos, de vagos a determinados, enriqueciéndose y precisándose siempre, pero sin contradecirse o trastornarse fundamentalmente, como llegó a pretenderlo la filosofía de Nietzsche. No debe confundirse la relatividad de todos los principios con su renovación indefinida, que no permitiría fundar otra filosofía que el pernicioso escepticismo. ${ }^{23}$

22 Góngora, ibid.

${ }^{23}$ Carlos Vicuña Fuentes, La Cuestión social ante la Federación de Estudiantes, 1922, Santiago, Imprenta y Litografía Sabater, p. 2. 
Esta postura estaba fundada en un principio ideológico que trataba de demostrar que el positivismo era una ‘doctrina orgánica’ que podía resolver “todos los problemas sociales y morales de la hora presente”.

Un artículo de Adolfo Allende S., publicado en Claridad en junio de 1920 titulado 'Nietzsche contra Wagner', analiza la relación entre ambos. Según el autor, Nietzsche admiró al músico pero pronto este sentimiento se transformó en adversidad y odio. Una de las causas fue el amor por la mujer que el músico le habría disputado y ganado al filósofo provocando que escribiera "El caso Wagner" donde injuria a su ex amigo. Otro motivo de la enemistad, según Allende, fue el deseo frustrado del filósofo de convertirse en compositor, por lo que habría recibido burlas del músico. En otro orden, más adelante puede leerse:

Nietzsche fue quien dijo: en la noche y en la semi-obscuridad de los bosques sombríos y de las cavernas, fue donde el oído, órgano del miedo pudo desarrollarse tanto como se ha desarrollado, gracias a la manera de vivir de la época de los terrores, es decir, de la más dilatada edad humana que ha existido. Cuando hay claridad el oído es mucho menos necesario. De ahí el carácter de la música, arte de la noche y de la semiobscuridad. $^{24}$

Para Allende uno era el hijo predilecto de la burguesía y veía la ópera sentado al lado del rey Luis de Baviera, poseía a la codiciada mujer y era admirado y envidiado; el otro, lleno de odio y rencor, tuvo que retirarse de la universidad donde enseñaba, sus libros no se vendían ni causaban revuelo, finalmente, murió enfermo de disentería.

Claridad interrumpió su aparición en 1926 y volvió a editarse en 1931, cuando había caído la dictadura de Ibáñez. Pese a las intenciones del grupo esta segunda época tuvo una corta vida, no obstante su línea se mantuvo inalterable, sintiéndose la influencia de los españoles en un cruce de nihilismo, nietzscheanismo y anarquismo. Según Gorkin,

${ }^{24}$ Adolfo Allende S., "Nietzsche contra Wagner”, Claridad, n 19 , Santiago, 4 de junio de 1921. 


\section{FABIO MORAGA}

el individualismo y el nihilismo de los escritores de la Generación del 98 condujeron a un escepticismo intelectual. Por ejemplo, Unamuno, que en su juventud había sido socialista, abandonó toda militancia y terminó sosteniendo la inexistencia de las clases sociales, mientras Pío Baroja se dedicaba a combatir el socialismo obedeciendo a su profundo individualismo ya que, según él, la doctrina de izquierda significaba la muerte del individuo. Según este autor, los escritores españoles, aunque excepcionales en su calidad estética, se habían alejado de las luchas políticas y sociales porque además de su individualismo llevaban una vida mísera en un país donde el sesenta por ciento de la población era analfabeta. ${ }^{25}$

El fenómeno también estaba marcado por una actitud errática en sus militancias políticas. Algunos habían tenido las más curiosas evoluciones pasando de monarquistas y conservadores a revolucionarios y republicanos: Azorín había sido anarquizante, enseguida federalista terminando al lado del reaccionario La Cierva, responsable del fusilamiento del ácrata Francisco Ferrer.

En la joven generación de Claridad, algunos se refugiaron en el cómodo pasado, como lo hiciera el conservadore Del Valle Inclán, mientras que otros, como Joaquín Arderiuz, parecían influenciados por el primer Baroja, dados los elementos nihilistas y anarquizantes, Nietzsche y Dostoievsky. En todo caso ya no existía el reconocimiento gratuito o ingenuo de 'maestros de juventud' ni tenían padres ideológicos como tuvo la generación del veinte.

\section{VI. ¿Hubo una ‘izquierda nietzscheana’?}

Durante las primeras décadas del siglo Xx, las vanguardias artísticas y políticas europeas leyeron a Nietzsche influidas por tres grandes fenómenos. Primero, la crisis de las ideologías que habían alimentado

${ }^{25}$ Cfr. J. G. Gorkin, “Los escritores de España”, Claridad, n 137, 29 de agosto de 1931. 
por siglos a sus sociedades: el cristianismo católico y protestante; el racionalismo cientificista dieciochesco y decimonónico, y el ideal del progreso unido al liberalismo político. Un segundo elemento, conectado íntimamente con el primero, fue la crisis producida por la Primera guerra mundial, que puso en evidencia la ausencia de una ideología que explicara satisfactoriamente el porqué de la conflagración. Estos fenómenos unidos a la presencia ‘amenazante’ para la cultura occidental y cristiana de la revolución bolchevique, hicieron que la segunda lectura de Nietzsche se realizara en clave fascista, en tanto su discurso rescataba el valor de las acciones irracionales frente a lo inefectivo del racionalismo que había precipitado a Europa a una crisis inédita. De este modo Nietzsche contribuyó a alimentar la teoría de la reacción más salvaje a que fue sometida la sociedad europea durante el siglo.

En América Latina, libre de los traumas del viejo continente, la lectura de Nietzsche se hizo ‘desde la izquierda’ rescatando sus claves emancipadoras. Si bien sus obras llegaron mal traducidas y tergiversadas a los lectores hispanos, también lo fueron para los que leían el alemán. Esto, sin embargo, no impidió a los primeros comprender el significado real de los escritos nietzscheanos. Tanto Roca, como Mariátegui y los anarquistas chilenos los utilizaron para elaborar reflexiones y propuestas culturales y políticas renovadoras. Los primeros integraron el pensamiento del alemán en reflexiones ideológicas originales, heterodoxas y eclécticas, olvidadas o ignoradas por nuestra historiografía intelectual. Los ácratas chilenos fueron más allá, se inspiraron en Nietzsche para, además de ejercer la crítica cultural, fundamentar su individualismo, escribir poesía y la acción política.

La sociedad americana de principios de siglo, hegemonizada culturalmente por la oligarquía, entró en una crisis cultural e ideológica profunda pero distinta de la europea. Esto abrió posibilidades para que una gran cantidad de nuevas ideas fuera recibida y producida en nuestros países.

Para finalizar repetimos entonces la pregunta: ¿Cuál fue el real significado para este período de las ideas de Nietzsche en América? Pensamos que su obra alimentó las discusiones, propuestas y teorías de 


\section{FABIO MORAGA}

muchas personas que lucharon, desde distintos espacios, por el cambio de la sociedad. Esta singularidad respondió al carácter de las vanguardias artísticas y políticas de nuestro continente. Estudiantiles, liberales, anarquistas, etc., leyeron a Nietzsche rescatando los elementos que permitían criticar a la sociedad oligárquica contra la cual luchaban. Al no experimentar una nacionalidad perdida, ni una derrota en la guerra, los izquierdistas latinoamericanos ‘usaron’ el pensamiento del alemán para intentar demoler a martillazos los fundamentos de la sociedad oligárquica.

Pero este fenómeno no hubiese sido posible si nuestros nietzscheanos hubiesen leído 'al pie de la letra'. Ellos lo hicieron resignificando los conceptos, llenándolos de nuevos sentidos, ya que las palabras del alemán, como la de todos los teóricos europeos no les 'decían’ lo mismo que a sus interlocutores inmediatos. La sociedad americana tenía otros desafíos, otros lastres que detenían los cambios, había, entonces que leer adaptando y reinterpretando los significados, como lo hiciera Mariátegui con el conjunto de su obra.

Así, el pensamiento de Nietzsche significó una 'irrupción de nuevos sentidos', de nuevas formas de leer (y transformar) la sociedad a través de la acción individual y la crítica cultural como motor del cambio social. En este caso Nietzsche sirvió para sentar las bases de una original e inacabada teoría de la revolución. 